\title{
Effect of light curing tip distance and resin shade on microhardness of a hybrid resin composite
}

\section{Efeito da distância da ponta do aparelho de fotoativação e da cor na microdureza superficial de um compósito híbrido}

\author{
Flávio Henrique Baggio Aguiar* \\ Carolina Rodrigues Lazzari** \\ Débora Alves Nunes Leite Lima*** \\ Glaucia Maria Bovi Ambrosano**** \\ José Roberto Lovadino $* * * * *$
}

\begin{abstract}
Resin composite shades and resin composite polymerization performed with a distanced light tip are factors that can affect polymerization effectiveness. This in vitro study aimed to evaluate the influence of curing tip distance and resin shade on the microhardness of a hybrid resin composite (Z250 - 3M ESPE). Forty-five resin composite specimens were randomly prepared and divided into nine experimental groups $(n=5)$ : three curing tip distances $(2 \mathrm{~mm}, 4 \mathrm{~mm}$, and $8 \mathrm{~mm}$ ) and three resin shades (A1, A3.5, and C2). All samples were polymerized with a continuous output at $550 \mathrm{~mW} / \mathrm{cm}^{2}$. After 24 hours, Knoop microhardness measurements were obtained on the top and bottom surfaces of the sample, with a load of 25 grams for 10 seconds. Five indentations were performed on each surface of each sample. Results showed that bottom surface samples light-cured at $2 \mathrm{~mm}$ and $4 \mathrm{~mm}$ presented significantly higher hardness values than samples light-cured at $8 \mathrm{~mm}$. The resin shade A1 presented higher hardness values and was statistically different from C2. The resin shade A3.5 did not present statistical differences from A1 and $\mathrm{C} 2$. For the top surface, there were no statistical differences among the curing tip distances. For all experimental conditions, the top surface showed higher hardness values than the bottom surface. It was concluded that light curing tip distance and resin shade are important factors to be considered for obtaining adequate polymerization.
\end{abstract}

DESCRIPTORS: Composite resins; Hardness.

\begin{abstract}
RESUMO: A cor do compósito e a polimerização realizada com a ponta do aparelho de fotoativação distante da superficie do compósito são fatores que podem afetar a efetividade de polimerização. Assim, o objetivo deste estudo in vitro foi avaliar a influência desses fatores na microdureza superficial de um compósito híbrido (Z250 - 3M ESPE). Quarenta e cinco espécimes de compósito foram aleatoriamente preparados de acordo com os nove grupos experimentais $(n=5)$ : três distâncias de fotoativação $(2 \mathrm{~mm}, 4 \mathrm{~mm}$ e $8 \mathrm{~mm})$ e três cores de compósito $(\mathrm{A} 1, \mathrm{~A} 3,5$ e C2). Todas as amostras foram fotoativadas com aparelho de fotoativação ajustado com intensidade contínua de $550 \mathrm{~mW} / \mathrm{cm}^{2}$. Após 24 horas, dez medidas de dureza Knoop foram obtidas nas superficies de topo e fundo de cada amostra, com carga de 25 gramas por um tempo de 10 segundos. Resultados mostraram que, para a superficie de fundo, os grupos com a fotoativação realizada com distância de 2 e $4 \mathrm{~mm}$ apresentaram maiores médias do que os grupos com distância de $8 \mathrm{~mm}$, e os grupos de cor A1 apresentaram maiores médias e com diferenças estatísticas que os grupos de cor C2, e o grupo A3,5 não apresentou diferenças estatísticas quando comparado aos outros grupos. Para a superficie de topo, não houve diferenças estatísticas significantes para os fatores estudados. Para todas as condições experimentais, a superficie de fundo apresentou médias de durezas estatisticamente menores do que as da superficie de topo. Pode-se concluir que os fatores cor do compósito e distância de polimerização são importantes fatores a serem considerados para a obtenção de adequada polimerização.
\end{abstract}

DESCRITORES: Resinas compostas; Dureza.

\section{INTRODUCTION}

Light-activated resin composite, introduced in the 1970s, revolutionized clinical dentistry by maximizing working time and minimizing setting time ${ }^{17}$. Improvements in resin composite mechani-

\footnotetext{
*PhD, Assistant Researcher, Department of Restorative Dentistry; **Undergraduate Student, Department of Restorative Dentistry; ${ }^{* *}$ PhD Student, Department of Restorative Dentistry; ****Assistant Professor, Department of Social Dentistry/Statistics; $* * * *$ Chairperson, Department of Restorative Dentistry - Piracicaba School of Dentistry, Campinas State University.
} 
Aguiar FHB, Lazzari CR, Lima DANL, Ambrosano GMB, Lovadino JR. Effect of light curing tip distance and resin shade on microhardness of a hybrid resin composite. Braz Oral Res 2005;19(4):302-6.

cal properties and light curing devices have permitted their use in posterior teeth with greater reliability than was the case some years ago $^{7,9}$. In order to obtain optimal physical properties and clinical performance in resin composite restorations, it is necessary for a dental resin composite to have the most possible quantity of its monomer converted to polymer during the polymerization reaction ${ }^{19}$. Effective polymerization of the adhesive bond system and resin composite is required to obtain long-term clinical success.

However, there are many variables that affect the amount of light energy received at the top and bottom surfaces of a resin composite restoration, resulting in ineffective polymerization, such as the design and size of the light guide, distance of the light guide tip from the resin composite, power density, exposure duration, shade and opacity of the resin composite, increment thickness and material composition ${ }^{4,11,16}$. If the restoration does not receive sufficient total energy, various problems may arise, e.g., reduced degree of conversion, increased cytotoxicity, reduced hardness, increased pigmentation, decreased dynamic elasticity modulus, increased wear, increased marginal breakdown and weak bond among the tooth, adhesive and the restoration ${ }^{5,11,16}$.

The distance of the light guide tip from the resin composite is a factor that is difficult to control, because it depends on the caries progression, the cavity size and cavity position. When the distance is greater than $2 \mathrm{~mm}$, the light dispersion of the light curing unit increases, and it becomes difficult to obtain effective polymerization. Clinically, deficient polymerization can happen in deeper Class I and Class II cavities, due to the dispersion of light energy that occurs because of the distance between the light curing tip and the first resin composite increment ${ }^{10}$.

In a deeper Class II cavity, the interface between the first increment of resin composite and the tooth structure may be less polymerized, and exposure of this interface to the oral environment can generate marginal discoloration, restoration fractures and resin composite and adhesive solubility, leading to microleakage and secondary caries. If the less polymerized resin composite comes into contact with the pulpal and axial walls of the cavity, the remaining monomer can result in postrestorative sensitivity, because of its toxicity. These monomers can easily diffuse inward beyond the dentin and cause an inflammatory reaction in the pulp, resulting in sensitivity. If this process con- tinues unchecked, the inflammatory process can cause pulp necrosis ${ }^{2}$.

Few studies have been carried out to determine the depth of resin composite cure in situations in which the light curing tip is distanced from the filling material, as in the above-mentioned clinical situations. Thus, this study hypothesizes that in the deeper increments of a cavity, light shade resin composites can be used to obtain adequate polymerization, since they do not have any esthetic involvement. When the increment is close to the light curing tip (last increment), the correct resin composite shade (usually darker shades) can be used. The aim of this in vitro study was to evaluate the effect of light curing tip distance and resin shade on the hardness of the top and bottom resin composite surfaces.

\section{MATERIAL AND METHODS}

To conduct this study, a hybrid resin composite Z250 (3M-ESPE Dental Products, St. Paul, MN, USA) was used. Forty five cylindrical specimens were prepared in Teflon ring molds, $4.0 \mathrm{~mm}$ in internal diameter and $2 \mathrm{~mm}$ in depth, held between two glass slabs separated by milar matrix strips (Dentsply, Petrópolis, Brazil), and then pressed with a $500 \mathrm{~g}$ static load. The cavity was randomly filled in one increment and polymerized according to nine experimental groups $(n=5)$ : three curing tip distances $(2 \mathrm{~mm}, 4 \mathrm{~mm}$, and $8 \mathrm{~mm}$ ) and three resin shades (A1, A3.5, and C2). All samples were polymerized with a continuous output at $550 \mathrm{~mW} /$ $\mathrm{cm}^{2}$ (XL 3000 - 3M Espe - Grafenau, Germany) for 20 seconds. Polymerization was performed with the light tip positioned in a device, the light curing tip being $2 \mathrm{~mm}, 4 \mathrm{~mm}$ or $8 \mathrm{~mm}$ distant from the top surface of the sample (controlled by an electronic digital caliper - 3M Corporate Headquarters, St. Paul, USA).

Each specimen was removed from the mold and stored in a lightproof container at $37^{\circ} \mathrm{C}$ and $95 \% \pm 5$ relative humidity for 24 hours. After this period, the samples were washed and the hardness on the bottom and top surfaces of each specimen was tested using a Knoop hardness test (FM - Future Tech Corp., Tokio, Japan) under a $25 \mathrm{~g}$ load for $10 \mathrm{~s}$. Five measurements were taken at the approximate center of the specimen ${ }^{9}$. The values obtained in micrometers were converted to Knoop Hardness Number (KHN) in a computer software (Excel for Windows ${ }^{\circledR}$ - Microsoft Ind., CA, USA).

The Knoop hardness results of the top and bottom surfaces were submitted to subdivided par- 
Aguiar FHB, Lazzari CR, Lima DANL, Ambrosano GMB, Lovadino JR. Effect of light curing tip distance and resin shade on microhardness of a hybrid resin composite. Braz Oral Res 2005;19(4):302-6.

cels ANOVA (Split Plot) test $(p=0.05)$ and Tukey's test at the 5\% significance level. The factors light curing tip distance and resin shade were considered in the parcels and the factor surface (top or bottom) was considered in the sub-parcel.

\section{RESULTS}

The microhardness test results are presented in Tables 1 and 2 and Graph 1. ANOVA revealed significant differences among the factors light curing tip distance and resin shade, and a double interaction between curing tip distance and surface. Tukey's test was applied to individual comparisons $(p=0.05)$. Within the light curing tip distance, bottom surface samples light-cured at $2 \mathrm{~mm}$ and $4 \mathrm{~mm}$ presented higher hardness values than samples light-cured at $8 \mathrm{~mm}$ (Table 2). For the top surface, there were no statistical differences among the curing tip distances (Table 1). Within the factor resin shade, there were statistical dif-

TABLE 1 - Hardness means (KHN) for top surface $( \pm \mathrm{SD})$.

\begin{tabular}{c|c|c|c}
\hline \hline \multirow{2}{*}{ Resin shade } & \multicolumn{3}{|c}{ Light curing tip distance $(\mathrm{mm})$} \\
\cline { 2 - 4 } & 2 & 4 & 8 \\
\hline \multirow{2}{*}{$\mathrm{A} 1$} & 78.10 & $71.34(9.2)$ & 73.93 \\
& $(8.35) \mathrm{Aa}$ & $\mathrm{Aa}$ & $(9.17) \mathrm{Aa}$ \\
\hline \multirow{2}{*}{$\mathrm{A} 3.5$} & 74.36 & 71.69 & 70.53 \\
& (13.69) Aa & (9.62) Aa & $(9.74) \mathrm{Aa}$ \\
\hline \multirow{2}{*}{$\mathrm{C} 2$} & 77.92 & 71.84 & 72.36 \\
& (13.95) Aa & (8.62) Aa & (11.69) Aa \\
\hline \hline
\end{tabular}

Mean values with the same letter were not statistically different $(p>0.05)$ (same lower case letter indicates lack of statistical difference for the comparison among the same tip distance groups, and same upper case letter indicates lack of statistical difference for the comparison among different resin shades).

TABLE 2 - Hardness means (KHN) for bottom surface $( \pm \mathrm{SD})$.

\begin{tabular}{c|c|c|c}
\hline \multirow{2}{*}{$\begin{array}{c}\text { Resin } \\
\text { shade }\end{array}$} & \multicolumn{3}{|c}{ Light curing tip distance $(\mathrm{mm})$} \\
\cline { 2 - 4 } & 2 & 4 & 8 \\
\hline \multirow{2}{*}{$\mathrm{A} 1$} & $\begin{array}{c}37.35(6.52) \\
\mathrm{Aa}\end{array}$ & $\begin{array}{c}34.18(7.06) \\
\mathrm{Aa}\end{array}$ & $\begin{array}{c}23.39(7.75) \\
\mathrm{Ab}\end{array}$ \\
\hline \multirow{2}{*}{$\mathrm{A} 3.5$} & $\begin{array}{c}36.72(7.55) \\
\mathrm{ABa}\end{array}$ & $\begin{array}{c}33.55(6.66) \\
\mathrm{ABa}\end{array}$ & $\begin{array}{c}22.72(6.63) \\
\mathrm{ABb}\end{array}$ \\
\hline \multirow{2}{*}{$\mathrm{C} 2$} & $\begin{array}{c}33.05(6.22) \\
\mathrm{Ba}\end{array}$ & $\begin{array}{c}32.19(5.64) \\
\mathrm{Ba}\end{array}$ & $\begin{array}{c}20.15(7.76) \\
\mathrm{Bb}\end{array}$ \\
\hline \hline
\end{tabular}

$\overline{\text { Mean values with the same letter were not statistically different }}$ $(p>0.05)$ (same lower case letter indicate lack of statistical difference for the comparison among the same tip distance groups, and same upper case letter indicate lack of statistical difference for the comparison among different resin shades). ferences only on the bottom surface (Tables 1 and 2). A1 showed higher hardness values which were statistically different from those of C2. A3.5 did not show any statistical differences from $\mathrm{A} 1$ and C2 (Table 2). For all experimental conditions, the top surface showed higher hardness values than the bottom surface.

\section{DISCUSSION}

This investigation evaluated the influence of the resin composite shades and the distance between the resin composite and the light-curing tip on the microhardness of the top and the bottom resin composite surfaces. The results showed that for the top surface, there were no statistical differences for the studied factors. However, for the bottom surface, there were differences in the two factors studied. For all experimental conditions, the top surface showed higher hardness values than the bottom surface. These results demonstrated that there was a need to use light resin composite shades in all experimental distances of the light-curing tip from the top surface of the resin composite.

Adequate polymerization is a crucial factor in obtaining an optimal physical performance of these materials ${ }^{6}$, and it is related to better clinical performance. However, there are many variables that affect the amount of light energy received at the top and bottom surfaces of a resin composite restoration. Among these factors, the distance of the light guide tip from the resin composite and

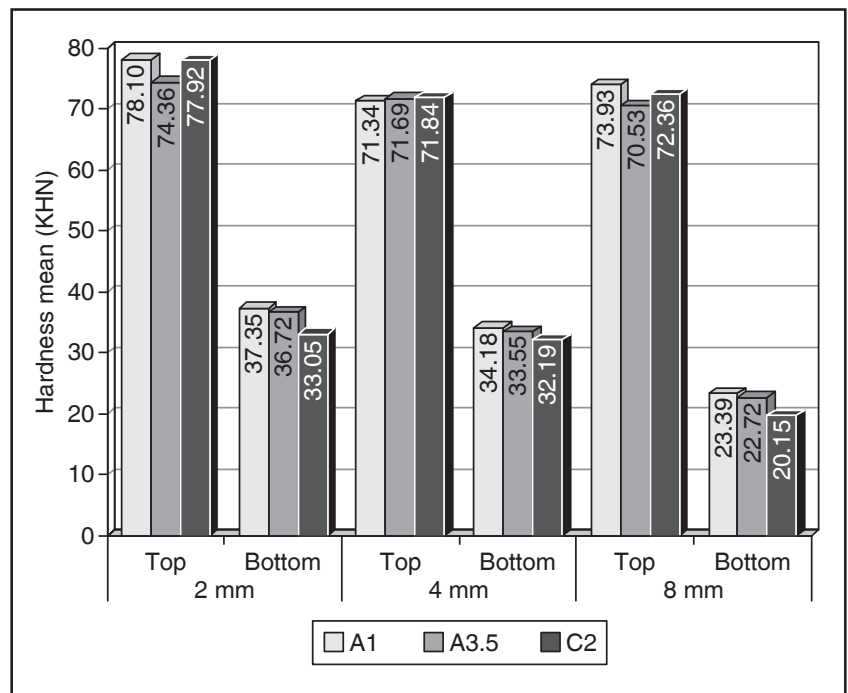

GRAPH 1 - Results of microhardness (KHN) for the experimental groups. 
Aguiar FHB, Lazzari CR, Lima DANL, Ambrosano GMB, Lovadino JR. Effect of light curing tip distance and resin shade on microhardness of a hybrid resin composite. Braz Oral Res 2005;19(4):302-6.

shade and opacity of the resin composite were analyzed in this study. The results of this study showed that these two factors were capable of affecting polymerization microhardness. Clinicians must be careful when they are faced with a clinical situation in which the pulpal, axial or the gingival walls of the cavity are distant from the light guide tip and a dark resin shade is to be used.

Results showed that resin shade is a factor that can alter polymerization efficacy. In this study, for the bottom surface, A1 showed highest hardness means and was statistically different from C2. A3.5 resin shade presented intermediate hardness means and did not show statistical differences from A1 and C2. Light transmission through the dark shades is diminished because of opacity ${ }^{13}$. Opaque shades decrease the capacity of the light to penetrate into the bulk of the resin composite ${ }^{8}$. However, different resin composites of the same Vita shade have different color values, and large quantitative color differences were detected among different resin composites of the same Vita shade ${ }^{14}$. Thus, it is possible to find different results in the literature, and these results can vary according to the composition of the resin composite used.

Another factor studied was the light guide tip distance. Results showed that, for the bottom surface, the $2 \mathrm{~mm}$ and $4 \mathrm{~mm}$ light tip guide distances did not show significant differences, but both distances were statistically different from the $8 \mathrm{~mm}$ light tip distance. These results are in agreement with those of Correr Sobrinho et al. ${ }^{4}$ (2000) and Caldas et al. ${ }^{3}$ (2003), who stated that resin composite polymerization depends greatly on the distance from the curing tip. Prati et al. ${ }^{10}$ (1999) demonstrated that the distance between the light guide and the resin composite can affect the light intensity, and that $1 \mathrm{~mm}$ of air reduces light intensity by approximately $10 \%$. In addition to the distance, another factor that attenuates light intensity is the resin composite. This may explain why only the bottom surface was affected by the two factors studied.
On the top surface, no significant difference in hardness was observed among the experimental groups. This statement is in agreement with the Yap et al. ${ }^{18}$ (2003) study, which concluded that the top surface hardness of resin composites was less dependent on light intensity than the bottom surface. In this study, both factors did not influence the hardness of the top surface. However, the results showed that, on the bottom surface, the distance of $8 \mathrm{~mm}$ and the $\mathrm{C} 2$ resin shade significantly decreased the hardness of the resin composite. The resin composite has the property of dispersing the light of the light curing unit, thus when the light passes through the bulk of the composite, light intensity is reduced due to the light being scattered by filler particles and the resin matrix ${ }^{4,10,18,19}$.

Yap et al. ${ }^{18}$ (2003) stated that the hardness ratio between bottom and top surface should be " 1 " in order to consider the polymerization completely effective, but a ratio of up to "around 0.8 " could be considered as an adequate polymerization. In this study, the results showed that the ratio was between 0.49 and 0.42 for groups in which the light guide was 2 and $4 \mathrm{~mm}$ distant, and between 0.32 and 0.27 for groups in which the light guide was $8 \mathrm{~mm}$ distant (Table 3 ).

This lower ratio was affected both by resin composite increment $(2 \mathrm{~mm})$ and the high distance from the resin composite to the light source. Both the studies by Soh et al. ${ }^{15}$ (2003) and Yap et al. ${ }^{18}$ (2003) showed ratios between bottom and top surfaces of 1 to 0.84 for the former and 0.97 to 0.69 for the latter, but in both studies the light guide tip was closed to the resin composite top surface. In some situations, clinicians can be faced with cavities $8 \mathrm{~mm}$ deep or more, and as the distance between the light guide and the floor of the cavity is a factor that is difficult to control, mainly in Class II cavities, the $2 \mathrm{~mm}$ increment should be reconsidered. Rueggeberg et al. ${ }^{12}$ (1994) suggested an increment of $1 \mathrm{~mm}$ as a way of improving resin composite polymerization and Atmadja, Bryant ${ }^{1}$ (1990) concluded that optimum polymerization is obtained with a greater degree of certainty by re-

TABLE 3 - Hardness ratio between bottom and top surface hardness means (KHN).

\begin{tabular}{|c|c|c|c|c|c|c|c|c|c|}
\hline & \multicolumn{3}{|c|}{$2 \mathrm{~mm}$} & \multicolumn{3}{|c|}{$4 \mathrm{~mm}$} & \multicolumn{3}{|c|}{$8 \mathrm{~mm}$} \\
\hline & Top & Bottom & Ratio & Top & Bottom & Ratio & Top & Bottom & Ratio \\
\hline A 1 & 78.10 & 37.35 & 0.4782 & 71.34 & 34.18 & 0.4791 & 73.93 & 23.39 & 0.3164 \\
\hline A3. 5 & 74.36 & 36.72 & 0.4938 & 71.69 & 33.55 & 0.4679 & 70.53 & 22.72 & 0.3221 \\
\hline $\mathrm{C} 2$ & 77.92 & 33.05 & 0.4242 & 71.84 & 32.19 & 0.4481 & 72.36 & 20.15 & 0.2785 \\
\hline
\end{tabular}


Aguiar FHB, Lazzari CR, Lima DANL, Ambrosano GMB, Lovadino JR. Effect of light curing tip distance and resin shade on microhardness of a hybrid resin composite. Braz Oral Res 2005;19(4):302-6.

ducing the thickness of the increment rather than by increasing the exposure time. Atmadja, Bryant ${ }^{1}$ (1990) and Prati et al. ${ }^{10}$ (1999) recommended increasing the polymerization time when the cavity is deep. The present study suggested that in deep cavities, dark shade resin composites should be avoided, and that the dark shade should only be used for the last increment when it is esthetically necessary.

\section{REFERENCES}

1. Atmadja G, Bryant RW. Some factors influencing the depth of cure of visible light-activated resin composite. Aust Dent J 1990;35:213-8.

2. Brännström M. The cause of post-restorative sensitivity and its prevention. J Endod 1986;12:475-81.

3. Caldas DBM, Almeida JB, Correr-Sobrinho L, Sinhoreti MAC, Consani S. Influence of curing tip distance on resin composite Knoop hardness number, using three different light curing units. Oper Dent 2003;28:315-20.

4. Correr Sobrinho L, Lima AA, Consani S, Sinhoreti MAC, Knowles JC. Influence of curing tip distance on composite Knoop hardness values. Braz Dent J 2000;11:11-7.

5. Ferracane JL, Greener EH. Fourier transform infrared analysis of degree of polymerization of unfilled resins: methods comparison. J Dent Res 1984;63:1093.

6. Knezevic A, Tarle Z, Meniga A, Sutalo J, Pichler G. Degree of conversion and temperature rise during polymerization of resin composite samples with blue diodes. J Oral Rehabil 2001;28:586-91.

7. Leinfelder KF, Bayne SC, Swift Jr EJ. Packable composites: Overview and technical considerations. J Esthet Dent 1999;11:234-49.

8. Leloup G, Holvoet PE, Bebelman S, Devaux J. Raman scattering determination of the depth of cure of light-activated composites: influence of different clinically relevant parameters. J Oral Rehabil 2002;29:510-5.

9. Manhart J, Kunzelmann K-H, Chen HY, Hickel R. Mechanical properties and wear behavior of light-cured packable resin composites. Dent Mater 2000;16:33-40.

\section{CONCLUSIONS}

Within the limits of this study, it can be concluded that:

- For all experimental conditions, the top surface showed higher hardness than the bottom surface.

- Light curing tip distance and resin shade are important factors to be considered for obtaining adequate polymerization.

10. Prati C, Chersoni S, Montebugnoli L, Montanari G. Effect of the air, dentin and resin-based composite thickness on light intensity reduction. Am J Dent 1999;12:231-4.

11. Price RB, Dérand T, Lonev RW, Andreou P. Effect of light source and specimen thickness on the surface hardness of resin composite. Am J Dent 2002;15:47-53.

12. Rueggeberg FA, Caughman WF, Curtis Jr JW. Effect of light intensity and exposure duration on cure of resin composite. Oper Dent 1994;19:26-32.

13. Sakagushi RL, Douglas WH, Peters MCRB. Curing light performance and polymerization of composite restorative materials. J Dent 1992;20:183-8.

14. Shortall AC, Wilson HJ, Harrington E. Depth of cure of radiation-activated composite restoratives - Influence of shade and opacity. J Oral Rehabil 1995;22:337-42.

15. Soh MS, Yap AUJ, Siow KS. Effectiveness of composite cure associated with different curing modes of LED lights. Oper Dent 2003;28:371-7.

16. Yap AUJ. Effectiveness of polymerization in composite restoratives claiming bulk placement: impact of cavity depth and exposure time. Oper Dent 2000;25:113-20.

17. Yap AUJ, Seneviratne C. Influence of light energy density on effectiveness of composite cure. Oper Dent 2001;26:460-6.

18. Yap AUJ, Wong NY, Siow KS. Composite cure and shrinkage associated with high intensity curing light. Oper Dent 2003;28:357-64.

19. Yoon TH, Lee YK, Lim BS, Kim CW. Degree of polymerization of resin composite by different light sources. J Oral Rehabil 2002;29:1165-73. 